\title{
LECTURERS' PROFESSIONAL IDENTITY: THE CASE OF CHARTERED ACCOUNTANTS IN ACADEMIA
}

\author{
E. Bitzer* \\ Department of Curriculum Studies \\ e-mail: emb2@sun.ac.za
}

\section{E. de Jager*}

Department of Accounting

e-mail: edejager@sun.ac.za

*Stellenbosch University

Stellenbosch, South Africa

\section{ABSTRACT}

This study surveyed a number of accounting lecturers at a research-intensive South African university to determine their perceptions and preferences regarding their own professional identity. How university lecturers see and experience their own professional identity is important as such views influence the way they teach, participate in professional learning opportunities and attach value to what they do. The findings indicate that professional identity is not a stable construct, that it is related to personal choices and influenced by a number of contextual factors. The participant group of accounting lecturers indicated their professional identity as primarily being professional lecturers rather than professional chartered accountants, but background variables did not seem to play a significant role in their professional identity formation, nor was role conflict identified as being a major factor. The findings imply that if accounting lectures consider themselves as professional university lecturers rather than professional chartered accountants, excelling as academics and educators would contribute towards excellence in the teaching of accounting.

Keywords: professional identity, accounting lecturers, professional education, chartered accountants, university lecturers, professional development.

\section{INTRODUCTION AND BACKGROUND}

The identity formation of academics who teach in professional education programmes in higher education institutions is under-researched (Beijaard, Meijer and Verloop 2004; Clarke, Hyde and Drennan 2013; Macfarlane 1998), but importantly, identity formation largely determines the way lecturers view their personal and professional development and contributions to higher education (Canrinus 2011). 
For many younger lecturers, lecturing is a second career - especially for accounting lecturers (Cross and Ndofirepi 2015; Steenkamp and Wessels 2009) as they often identify themselves strongly with their professional affiliations (Taylor 1999). Teaching in a business degree programme may pose a conflict of loyalties between academe and the profession (Macfarlane 1998), described by Sullivan (2005, 25 in Wells and Edwards 2013, 76) as 'hybrid ... with one foot in the academy ... and one foot in the world of practitioners'. In a very real sense, accounting lecturers are different from those academics who teach in the disciplines (Wilkerson 2010) and often their roles are influenced by different teaching and research demands (Samkin and Schneider 2014b).

Students sometimes hint that lecturers in professional programmes such as engineering are perceived as 'dull conformists' or that chartered accountants are 'boring' (Steenkamp and Wessels 2009, 121). While it may be important to determine how accounting lecturers are perceived by their students, the question arises how they perceive their own identity (Macfarlane 1998).

This study was conducted at a research intensive university where the Faculty of Economic and Management Sciences has the largest number of students and its chartered accounted programme is one of the top three in the country. Qualifying as a chartered accountant is a long and strenuous path to follow, but provides a gateway to a challenging and exciting career, global mobility, flexibility and good earning potential in a business field of choice (SAICA 2015). In order to become an accounting lecturer at most South African universities, an individual has to be a qualified chartered accountant (CA) and remain a CA during their academic career. The question often emerges as to why a professional person would decide to join a university as an academic staff member and thereby forfeit the professional status of being a CA rather than entering or remaining in the corporate world?

Earlier, Simon (1976) identified the typical academic professional educator as someone who is either young, having attained relatively modest professional experience, or nearing retirement and is unable to keep up with the demands of professional practice. This label might not hold true for current CA lecturers in South Africa, where historical inequalities are being increasingly addressed and practical considerations such as flexible working hours, the chance to contribute to a field as a specialist and opportunities to support students to develop as accountants are but a few of the issues influencing a career in academe.

In addition, those who become accounting lecturers are expected to be knowledgeable and competent, not only in their field of specialisation, but also in the pedagogy of Accounting (Komba, Anangisye and Katabaro 2013). Accounting educators are thus bound by two 
contracts: one pertaining to higher education and the other to the CA profession (Wilkerson 2010).

As higher education is increasingly prone to new liberal thought (Giroux 2014) and governed by market forces, numerous demands are placed on lecturers (Hargreaves 2000; Canrinus 2011). They are expected to keep their knowledge and skills recent and to develop professionally - both within their field of expertise and as educators. They are also required to make use of continuous professional development opportunities and to invest time in their fields and subjects of specialisation (Trede, Macklin and Bridges 2012; Komba et al. 2013). Accounting lecturers, in particular, are expected to further develop as CAs in accordance with the requirements of the South African Institute for Chartered Accountants (SAICA 2015) and to keep track with innovative teaching and learning developments (SU Strategy for Teaching and Learning 2015). An understanding of how one sees one’s identity as CA, academic or both, inevitably has implications as to the kind of professional development needed (Coldron and Smith 1999).

Professional identity seems often problematic for lecturers as they juggle between expectations, roles and employment conditions (Beijaard et al. 2004). This may be particularly true for accounting teachers at research intensive universities where the sentiments are often not in favour of good teaching (Samkin and Schneider 2014b) and where the concept of a 'scholarship of teaching' (Boyer 1990) emerged to redefine the importance of research into teaching. Many accounting lecturers would agree that their main purpose is to prepare students to enter commercial careers (Macfarlane 1998), but the manner in which this is best achieved is far from universal or clear. Some argue that content knowledge is prime, while others also emphasise the value of generic competencies such as communication, problem solving and team work. A combination of content knowledge and generic skills may provide a sound basis for students to excel in business careers (Trede, Macklin and Bridges 2012; SAICA 2015).

It is thus expected that lecturers' views of their professional own identity would affect their agency, their willingness to participate in professional learning opportunities and ultimately the quality of what and how they teach (Beijaard, Verloop and Vermunt 2000; Beijaard et al. 2004), how their students learn (Auyeung and Sands 1997) and their individual effectiveness within an organisation (Rizzo, House and Lirtzman 1970). Professional identity is also considered a key factor in the motivation, effectiveness and retention of academics (Hong 2010), all vital in contributing to teaching excellence (Beijaard et al. 2000). 


\section{LECTURER IDENTITY}

A professional is someone who has been approved by a profession as a registered practitioner with the right to exercise autonomous, professional judgment (Hooley 2007, 50). In the case of chartered accountants, for instance, it requires specialist, esoteric, technical and applied knowledge within a set of agreed values (Empson 2004).

The term 'identity' is often viewed in terms of the characteristics of a person or group (Beijaard 1995), while others see identity as formed by an ongoing process of life experiences (Kerby 1991). Erikson (1968) describes identity as not something that one has, but something that develops during a lifetime.

Professional identity is thus a multi-layered concept, often interpreted in terms of individuals' perceptions of themselves as part of their professional practice (Canrinus 2011). Professional identity as a lecturer, for instance, may be defined in terms of how strongly a person associates with the goals and values of education, teaching and learning (Cheung 2008).

Traditionally, subject or disciplinary knowledge was the most important part of a lecturer's professional base (Bromme 1991), but more recently, however, elements such the facilitation of learning within context, ethics and community-sensitive learning have also become important within the reigning philosophy of student-centred learning and teaching (Beijaard et al. 2000; Costandius and Bitzer 2015). An interconnection between professional standards (e.g. norms and values), a commitment to standards and an ability to develop within a profession are mentioned as important features of professional identity (Canrinus 2011; Komba et al. 2013).

In addition, professional identity as a lecturer is determined not only by how one sees oneself, but also by how others perceive teaching in a professional field such as accounting (King 2013). Recently, public perceptions of academics as professionals have evolved in different ways because of changes in higher education sector as a public or private good, pressures from constituents outside of universities as well as changing systemic and institutional demands (Billot 2010; Marcelo 2009; Waghid 2006; 2009).

The development of lecturer professional identity thus seems to be an evolutionary process and influenced by a variety of factors shaping the motivation, willingness, satisfaction and impact of university lecturers, which asks for a brief discussion of the role of accounting lecturers as academics.

\section{ACCOUNTING LECTURERS AS ACADEMICS}

The dual professional-academic role of the accounting lecturers seems inevitable (King, Garcia- 
Ferez, Graham, Jones, Tickle and Wilson 2014) as their professional status as chartered accountants provides meaning to their teaching. At the same time, their status as educators depend on how and how well they educate future accountants. In real terms, however, an accounting academic's role also involves activities such as consulting, standard setting, promoting ethical behaviour and many more (Cross and Ndofirepi 2015; Samkin and Schneider 2014a).

With respect to gender, more male than female lecturers consider themselves as subject matter experts and most female lecturers see themselves as being more 'balanced' between being professional educators and being professionals educating students (Beijaard et al. 2004). In addition, novice lecturers (those with less than 10 years of teaching experience) also consider themselves as subject matter experts, which implies that those with more teaching experience become more 'balanced' in viewing their own professional identities (Beijaard et al. 2000). Professional identity often evolves with experience (Huberman 1989; University of Manchester 2015), while a study by Hong (2010) found that academics in different stages of their careers perceive themselves differently - including their commitment to and efficacy regarding teaching.

In accounting departments at many universities lecturers do not need formal training in education to become a lecturer (Komba et al. 2013). At the University of Dar es Salaam, for instance, it was found that the concept of the professional lecturer appears to lean towards their professional orientation (Komba et al. 2013), while the 'structured technical syllabus' of CAs may have a crafting effect on their professional identity (Hamilton 2007).

Another factor contributing to identity formation is a passion (or the absence thereof) for teaching (Cross and Ndofirepi 2015). In one study (Cross and Ndofirepi 2015), teachers were asked what they did for a living. The meaning of an answer such as 'I am a teacher' was found to differ completely from the meaning of an answer like 'I work as a teacher'. This illustrates what was important to the respondents and resonates with questions such as 'Do I want to be an academic?', or 'Do I want to do what academics do?' (University of Manchester 2015). Answers to such questions are indicative of lecturers' sentiments and passion, while some studies also indicate that students prefer for lecturers to display teacher, rather than professional, identities (Weiss and Fisherman 2006).

In South Africa, all members of SAICA are required to maintain their professional competence and to participate in continuous professional development (CPD) as professional competence is one of the fundamental principles of SAICA's Code of Professional Conduct (SAICA 2013). Every CA has the responsibility to develop and maintain their professional 
competence, as is relevant to the nature of their work and professional responsibilities. Similarly, lecturers at most South African universities are expected to participate in teaching orientation programmes for newly appointed university lecturers, followed by more intensive developmental opportunities and the opportunity to pursue formal qualifications in the field of higher education teaching and learning (HELTASA 2015). A study by Lubbe (2014) confirms challenges faced by accounting academics, including a division between the requirements of professional accounting bodies and those of universities. The latter study found that accounting academics in South Africa (a developing country) are of the opinion that their main focus should be on being quality educators rather than being quality accountants. In addition, Skelton (2004) hast suggested the establishment of a national body to develop and promote teaching and learning in the professions with similar purposes than any other professional body.

Between the demands of serving the interests of their university and the accounting profession (Lubbe 2014), accounting academics also experience pressures towards research output (Samkin and Schneider 2014a). Such research may also include research into the teaching and learning of accounting (Lubbe 2014).

It is argued that professional identity guides one's professional actions and decisions, and if a CA as an accounting lecturer and does not embrace teaching excellence at all, professional identity becomes a barrier to the promotion of educational excellence (Brownell and Tanner 2012). The professional identity of lecturers may thus contribute towards teaching excellence where teachers demonstrate professionalism by their enthusiasm for what they teach, who they teach and how they teach (Ballantyne, Bain and Packer 1999). For excellent teachers (and teaching) to happen, lecturers should consider themselves primarily as educators (Shaftel and Shaftel 2005), while lectures' who strive for quality have a well-developed professional identity (Moore and Hofman 1988) and takes a scholarly approach to teaching (Healey 2000).

The professional identity of university lecturers, especially those at research-intensive universities, is far from a clear-cut issue and influenced by a variety of factors. Consequently, a study was conducted among a group of accounting lecturers at one research intensive South African university to determine such factors and its influence on professional practices within the particular university.

\section{METHOD}

\section{Research aim and question}

The professional identity formation of lecturers contributes in meaningful ways to their 
effectiveness and their level of motivation and willingness to further develop as professionals (Canrinus, Helms-Lorenz, Beijaard, Buitink and Hofman 2011). Should accounting lecturers perceive themselves more as university lecturers rather than CA's, then how they spend their time and energy may determine their professional development priorities. The research focus for the study was thus whether accounting lecturers perceive themselves professionally as chartered accountants or as university lecturers. In addressing this, three issues were inquired into, namely: (a) How accounting lecturers understand the term 'professional identity; (b) Accounting for some variables that play a role in how accounting lecturers perceive their professional identity; and (c) The preferred professional learning activities accounting lecturers participate in.

A questionnaire survey was used amongst 55 accounting lecturers at one South African research-orientated university. Individual lecturers returned completed questionnaires via internal mail (not e-mail) anonymously. Ethical clearance and institutional permission were obtained from the particular university.

\section{Data collection}

The first section of the questionnaire contained general biographical questions. The second part asked lecturers to rate statements about the importance of being a lecturer and the importance of being a CA on a 5-point Likert scale (varying from 1 to 5, where 1 = 'Don't agree at all' and $5=$ 'Totally agree'). The third part of the questionnaire required lecturers to allocate a weight to the two aspects of their professional life (being a lecturer or being a CA) and also to allocate a weight to the type of development opportunity (lecturer-related or CA-related) they prefer. The last part of the questionnaire consisted of two open-ended questions asking accounting lecturers what they understand by 'professional identity' and how they view themselves as professionals.

\section{Analysis}

The results of the questionnaire were analysed by using repeated measures analysis of variance (ANOVA) and the non-parametric Wilcoxon rank test. If the residuals from ANOVA are not normally distributed, the Wilcoxon test is more appropriate. Statistical significance was set at $\mathrm{p}<0.05$

The 55 accounting lecturers were provided with a list of statements on the importance of being a lecturer (statements 1 to 10) or being a CA (statements 11 to 20). A reliability test was performed for statements 1 to 10 which yielded a Cronbach's alpha of 0.784 , while statements 11 to 20 rendered a Cronbach alpha of 0.817 . Both values indicate that the statements are 
reliable and consequently the median and the mean were calculated for each group, i.e. 'Lecturer' and 'CA'.

Where lecturers were asked to allocate a weight to represent their professional identity in terms of the two aspects ('Lecturer' or 'CA') the results were analysed using T-tests for single means. Further tests were done to test to determine whether lecturers' background variables could possibly account for differences in perception.

\section{Participants}

All 55 lecturers with a professional CA (SA) qualification at the School of Accountancy at the participant university were invited to participate in the survey. The School of Accountancy at this institution offers the following disciplines: Financial Accounting, Taxation, Auditing, Management Accounting and Information systems. Courses either in the CA stream (B.Accounting programme) or the non-CA stream (B.Comm programme) and the CA (SA) are offered. Lecturers are involved in either one or both of these programmes. In the end a total of 28 questionnaires were returned, representing a 51 per cent response rate. The overall profile of the respondents is summarised in Table 1.

Table 1: Participant profile $(n=28)$

\begin{tabular}{|l|l|l|l|l|l|l|l|l|}
\hline \multicolumn{2}{|l}{} & $\mathbf{n}$ & & $\mathbf{n}$ & & $\mathbf{n}$ & & $\mathbf{n}$ \\
\hline Gender & Male & 5 & Female & 23 & & & & \\
\hline Age in years & $25-30$ & 13 & $31-40$ & 13 & $41-50$ & 2 & $>50$ & 0 \\
\hline Married & Yes & 24 & No & 4 & & & & \\
\hline Children & Yes & 12 & No & 16 & & & & \\
\hline $\begin{array}{l}\text { Number of years } \\
\text { lecturing }\end{array}$ & 1 & 5 & $2-5$ & 12 & $6-15$ & 10 & $>15$ & 1 \\
\hline Subject & $\begin{array}{l}\text { Financial } \\
\text { accounting }\end{array}$ & 17 & $\begin{array}{l}\text { Management } \\
\text { accounting }\end{array}$ & 2 & Taxation & 3 & & \\
\hline & $\begin{array}{l}\text { Information } \\
\text { systems }\end{array}$ & 3 & Auditing & 3 & & & & \\
\hline Course & CA stream & 12 & Non-CA stream & 9 & Both & 7 & & \\
\hline $\begin{array}{l}\text { Years previous } \\
\text { working experience }\end{array}$ & $0-1$ & 15 & $2-5$ & 8 & $6-15$ & 5 & $>15$ & 0 \\
\hline
\end{tabular}

Table 1 shows a clear participant trends in terms of dominant female numbers, relative young lecturers of whom most are married with six years or more lecturing experience, but also less experience as professional accountants. Some of these features will be picked up later in the discussion of the survey results. 


\section{FINDINGS AND DISCUSSION}

\section{How accounting lecturers perceive their professional identity}

An open question in the questionnaire asked accounting lecturers what they understand by the term 'professional identity'. A variety of responses emerged, where one respondent indicated that professional identity is '[F]ormed by the type of work that you do', while another said it is: 'Who and what you are at work'. A third referred to professional identity as 'Values, behaviours and attitudes built into your profession as a CA' and a fourth said: 'Regardless of the work that you are doing, you still maintain the characteristics of your profession'.

The range of comments from the accounting lecturers indicated three broad categories, namely that professional identity is (i) related to the context in which lecturers work and their daily work activities; (ii) related to the person and/or her or his professional affiliation, and (iii) defined in terms of acquired qualification(s). These views obviously informed their views as to what is important in terms of being a lecturer or a CA. The comment range also indicated that the term 'professional identity' does not have a singular definition and is indeed a multilayered concept (Huberman 1989; Hooley 2007; Canrinus 2011).

\section{The importance of being a lecturer versus a CA}

In the second part of the survey questionnaire, statements 1 to 10 (being a lecturer) were compared to statements 11 to 20 (being a CA). The median, mean as well as the p-value were calculated as shown in Table 2.

Table 2: Being a lecturer versus being a CA

\begin{tabular}{|l|c|c|}
\hline & Median & Mean \\
\hline A. Importance of identification (p= 0.8647) & & \\
\hline 1. It is important for me to be a lecturer. & 5 & 4.53 \\
\hline 11. It is important for me to be a CA. & & 4.50 \\
\hline B. Being comfortable with identification (p= 0.3505) & 5 & 4.71 \\
\hline 1. I am comfortable to introduce myself as a lecturer. & 5 & 4.42 \\
\hline 12. I am comfortable to introduce myself as a CA. & & \\
\hline C. Centrality of identity (p = 0.0173) & 4.5 & 4.71 \\
\hline 3. Being a lecturer is a central part of my life. & 4 & 4.42 \\
\hline 13. Being a CA is a central part of my life. & 5 & 4.57 \\
\hline D. Professional fulfilment (p= 0.0001) & 3 & 2.89 \\
\hline 4. I experience fulfilment as a lecturer. & & \\
\hline 14. I experience fulfilment as a CA. & 4 & 4.07 \\
\hline E. Professional purpose (p= 0.0011) & 3 & 2.96 \\
\hline 5. My main purpose at work is to educate students. & & \\
\hline 15. My main purpose at work is to train future CAs. & & \\
\hline
\end{tabular}




\begin{tabular}{|c|c|c|}
\hline & Median & Mean \\
\hline F. Professional excellence $(p=0.0049)$ & & \\
\hline 6. I want to be an outstanding lecturer. & 5 & 4.78 \\
\hline 16. I want to be an outstanding CA. & 4 & 4.17 \\
\hline G. Need for professional development $(p=0.0057)$ & & \\
\hline 7. I want to develop my competencies as a lecturer. & 5 & 4.75 \\
\hline 17. I want to develop my competencies as a CA. & 4 & 4.28 \\
\hline H. Utilisation of professional development opportunities $(p=0.7556)$ & & \\
\hline $\begin{array}{l}\text { 8. I use the opportunities that are presented by the university to develop my } \\
\text { competencies as a lecturer. }\end{array}$ & 4 & 4.07 \\
\hline $\begin{array}{l}\text { 18. I use continuous professional development (CPD) opportunities to develop } \\
\text { my competencies as a CA. }\end{array}$ & 4 & 4.03 \\
\hline I. Time spent on professional activities $(p=0.0001)$ & & \\
\hline 9. I spend most of my time at work on lecturer activities. & 4 & 4.10 \\
\hline 19. I spend most of my time at work on CA activities. & 3 & 2.53 \\
\hline $\begin{array}{l}\text { J. Time spent on professionally related activities } \\
(p=0.8888)\end{array}$ & & \\
\hline $\begin{array}{l}\text { 10. Outside working hours, I spend my time on activities that relate to my role } \\
\text { as a lecturer. }\end{array}$ & 3 & 2.5 \\
\hline $\begin{array}{l}\text { 20. Outside working hours, I spend my time on activities that relate to my role } \\
\text { as a CA. }\end{array}$ & 2 & 2.39 \\
\hline
\end{tabular}

The results from section A of Table 2 show that accounting lecturers regard being a lecturer as of equal importance than being a CA. In practice, being an accounting lecturer is dependent on being a CA, so it was expected that the sentiment regarding these two statements would not differ much. Some of the open-ended comments concurred with this. For instance, two lecturers emphasised: (1) 'The two roles can’t actually be split and have a mutual relationship’. (2) ‘I couldn't be a lecturer without being a CA'. While the duality of roles is confirmed by authors such as King et al. (2014), the mean of the two answers of this section are so close to each other that it can be assumed that both associations are deemed important.

Section B points to accounting lecturers being comfortable seeing themselves as either lecturers or CAs and no significant statistical difference was found in responses. One lecturer's open comment was: 'I am a CA who chose to lecture', while another respondent said: 'I am a lecturer with a CA qualification'. It may thus be assumed that these lecturers are comfortable with carrying both professional labels as earlier confirmed by Stone, Ellers, Holmes, Orgren, Qualters and Thompson (2002) for medical professionals.

Section $C$ indicates that accounting lecturers consider being a lecturer as more significant to their lives than being a CA. This could be explained by the fact that for the most part of each working day accounting lecturers are involved with academic activities. Being a lecturer demands that most time is spent on preparation for facilitating student learning and thus it forms a central part in professional duties. The difference in responses in this case was statistically significant (p-value 0.0173) and a number of respondents indicated via the open-ended questions that their daily activities include spending time on lecturing-related tasks. These 
results compare favourably with the results of a study by Lubbe (2014), where findings indicated that the involvement in teaching takes priority in the jobs of accounting lecturers.

In Section D it seems clear that fulfilment being an accounting lecturer is more prominent than fulfilment as a CA. The difference in responses between the two statements was statistically highly significant (p-value 0.0001 ), while in one of the supplementary questions, lecturers had to indicate the number of years worked as a CA prior to becoming a lecturer. Most respondents (75\%) worked as a CA before joining the particular university, but the average number of years work experience as CA was only between two and five years. This may explain the lower levels of professional satisfaction as a CA and tie in with findings by Lubbe (2014) that accounting lecturers enjoy teaching more as their university careers progress.

Statements 5 and 15 in section E also showed statistically significant differences (p-value 0.0011) where respondents considered their main professional purpose as including more than the training of future CAs. This finding links to earlier findings that the professional identity of lecturers is influenced by teaching students - even more so than being a subject expert themselves (Day, Kington, Stobart and Sammons 2006; Cross and Ndofirepi 2015). This finding also concurs with the responses to section $\mathrm{F}$ where the differences were also statistically significant (p-value 0.0049), but the answers to the two statements were quite different. For instance, the results of statement 6 ranged from 4 to 5, indicating that most respondents' desire to be outstanding lecturers, whereas the results of statement 16 ranged from 2 to 5, indicating that the respondents were of different opinions regarding being an outstanding CA. One participant summarised the professional excellence issue as: 'It is important for me to do well as a lecturer, but I do not want to under-estimate my CA qualification'.

The results of statements 7 and 17 in section $G$ indicate the need for professional development. The results were statistically significant (p-value 0.0057), however, the mean between the two statements did not differ that much, indicating that respondents obviously want to develop their competence, firstly as a lecturer, but also as an 'up to date' CA. One respondent stated, for instance: 'I use my CA competencies to teach and to present my lectures'. This resounds with a finding by Stone et al. (2002) that identity as a teacher can positively influence the motivation to participate in educational development activities.

Statements 8 and 18 in Section $\mathrm{H}$ have shown that respondents use the opportunities on offer to develop as lecturers and as CAs. However, when lecturers were asked later in the questionnaire to allocate a weight to the types of development opportunities utilised (lecturerrelated versus CA-related), they indicated that an average of 73 per cent of their time was spent on lecturer development opposed to only 27 per cent on CA-related development. One reason 
for the difference between the first set of statements and the indicated weight allocation could be that accounting lecturers probably want to spend equal time developing both aspects, but may not always have the opportunity to do so. This ties in with earlier by Sherman, Armistead, Fowler, Barksdale and Reif (1987) who found that lecturers would focus on developing teaching excellence should be appropriate and meaningful developmental interventions be available.

The results of responses to the questions in Section I relate to those in section E, since professional competence and excellence cannot be separated from the time spent on that profession. It was expected that the major part of lecturers' time would be spent on lecturer activities, as CA-related activities would typically include keeping up with professional CA knowledge and competencies. Lecturer activities, on the other hand, includes teaching, preparation of lectures, administration and consultations with students, all of which may contribute to teaching excellence. In addition, most respondents commented (in an open-ended question) that they spend much time on lecturer/teaching tasks, while only one respondent indicated that (s)he spend time at work on CA activities, which include advising customers. These findings concur with another South African study (Nieuwoudt, Wilcocks and Kilpert 2006) which indicated that academics in accounting spend at least 75 per cent of their time on teaching.

On the question of time spent outside of formal working hours (section $\mathrm{J}$ ) it seems that accounting lecturers, in general, do not spend time on activities that either relate to their role as a lecturer or their CA role outside of working hours. It thus seems unlikely that they would do 'outside' work. It might thus be that accounting lecturers do not have the time to do any 'outside' work or that lecturers would rather focus on academic-related activities such preparing for teaching or research.

Table 2 indicates overall a higher median for all the statements relating to being a lecturer (statements 1 to 10) than being a CA (statements 11 to 20). Accounting lecturers thus seem to identify more strongly with their roles as lecturers (median 5) than as their role as CAs (median 4). The responses on teaching ranged from 3 to 5 , indicating a higher rating for each statement when evaluated in terms of being a lecturer, while the CA statements ranged between 1.5 to 5 , indicating that the respondents held more varied views on being a CA. Overall it would be safe to conclude that the accounting lecturers in this study strongly associate with the importance, centrality and the development of their teaching role. 


\section{Factors in identity formation}

A lecturers' biography is an important determinant in professional identity formation (Beijaard et al. 2004). In this study, however, no single biographical variable significantly seemed to have influenced the perceptions of accounting lecturers. While this is also true for age as a variable, lecturers in their late 30s to mid-50s appear to be in the most productive phase of their academic life. However, a study by Clarke et al. (2013) indicated a somewhat lower association with being a lecturer (just below 70\%) for younger lecturers than for older lecturers (just over 70\%). This difference was, however, not statistically significant.

As for gender, a study conducted by Komba et al. (2013) indicated that more male lecturers identified themselves as being teachers, compared to female respondents. In our study, however, female respondents had a higher average association with being lecturers compared to male respondents. This difference was not statistically significant and the number of male respondents (5 out of 28) was insufficient for a fair representation. Yet, both female and male respondents perceived themselves as lecturers, rather than as CAs, which corresponds with the findings of the Komba et al. (2013) study.

Having a family may also influence the formation of professional identity (Beijaard et al. 2004). Clarke et al. (2013) found that women in accounting education have heavier domestic responsibilities, while Sugrue (1997) found that immediate family responsibilities play a role in shaping professional identity. In our study, however, no difference was found between the responses of married and unmarried accounting lecturers. Participants with children indicated a slightly higher average for seeing themselves as lecturers compared to those without children. It could be argued that accounting lecturers without dependants may have more time or ambition to pursue both an academic and accounting identity.

Participants in our study were either involved in teaching in the CA programme, the nonCA stream or in both. Although lecturers in neither stream receive training to become university lecturers, those involved in both streams (as opposed to those involved in only one of these streams) indicated a higher average of perceiving themselves as lecturers, rather than CAs. Conversely, the utilisation or uptake of CA developmental opportunities was statistically higher for CA stream lecturers than for non-CA stream lecturers. This could be explained by the fact that it is a requirement for CA stream lecturers to remain up to date with current accounting standards and also that more continuous professional development opportunities in accounting are available to them.

Komba et al. (2013) found that professors and senior lecturers were more likely to regard themselves as teachers than less experienced lecturers. Canrinus et al. (2011), however, reported 
that the professional identities of novice and experienced teachers were similar. The findings of our study concur with those of Komba et al. (2013), as lecturers with more years of university experience associated themselves more closely with being lecturers than those with less experience. This finding was, however, not statistically significant.

Overall, none of the background variables of the participating accounting lecturer group in our study showed any statistically significant differences in influencing perceptions of professional identity. Regardless of characteristics such as gender, age, family life and experience, lecturers throughout perceived their professional identities to be more in favour of being lecturers than CAs.

\section{Professional preferences regarding effort and development and overall perception}

Participants were also asked to allocate weights to the two aspects (being a lecturer and being a CA), making up a total of 100 per cent, as well as the type of development opportunity they had utilised (lecturer-related and CA-related) for professional development, also totalling 100 per cent of their time. The last survey question asked the accounting lecturers to indicate their professional preference when they had to choose between being a professional accounting lecturer or a professional CA, also providing a reason for their choice. The results are shown in Table 3 below.

Table 3: Views on professional effort, taking up development opportunities and professional preference

\begin{tabular}{|l|c|c|c|}
\hline \multicolumn{4}{|l|}{ Indicate how you see yourself in terms of: } \\
\hline & Effort & Development & Preference \\
\hline Lecturer & $70 \%$ & $73 \%$ & $50 \%$ \\
\hline CA & $30 \%$ & $27 \%$ & $36 \%$ \\
\hline Both & - & - & $14 \%$ \\
\hline & $\mathbf{1 0 0 \%}$ & $\mathbf{1 0 0 \%}$ & $\mathbf{1 0 0 \%}$ \\
\hline
\end{tabular}

Table 3 corresponds with the overall findings from the earlier Likert-type responses, namely that accounting lecturers see themselves firstly as lecturers (70\%) and then as CAs (30\%). This difference proved to be statistically significant. Table 3 also shows a significantly higher percentage allocated to opportunities utilised for lecturer-related development (73\%) compared to CA-related development (27\%). One explanation may be that lecturer-related development is more important to accounting lecturers, but it is also possible that the development opportunities available to them were more lecturer- or university-related.

It is interesting to note how the results from the final survey question differed from the 
other allocated weights. Whereas the accounting lecturers awarded 70 per cent to their effort as professional university lecturers, the question of preference only totalled 50 per cent. What may be apparent here (and was reflected in respondents' comments) is that accounting lecturers realise that their work primarily entails academic activities as an effort, but when asked to indicate their professional preference, they would rather not abandon or neglect their professional status as CAs. These results correspond to the findings by Retief Venter and De Villiers (2013), who interviewed heads of accounting departments regarding the accounting profession where one statement reads: 'If someone asked me today to sacrifice my CA qualification or my $\mathrm{PhD}$, I would give up my $\mathrm{PhD}$ any day'. It also corresponds to the results of a study by Brownell and Tanner (2012) who found that professional scientists consider it difficult to abandon their professional status and be seen as science teachers at a university school of biology in the USA.

It is thus evident that professionals in academe grapple with the issue of professional balance and are likely to continually renegotiate their professional identity between being a professional accounting lecturer and being a professional chartered accountant.

\section{CONCLUSIONS AND IMPLICATIONS}

Our study found, amongst other things, that professional identity as a phenomenon is complex, related to personal choice and influenced by various contextual factors. Professional identity is thus not a stable construct or entity (Clarke et al. 2013; Day et al. 2006). Taylor $(1999,43)$ summarises this well by stating that identity gives one '.. a sense of belonging, a feeling of personal significance and a sense of continuity and coherence'. Being a professional lecturer entails much more than teaching students and points to taking on the identity of an educator who forms and shapes future generations of professionals and practitioners (Sumara and LuceKapler 1996). Lubbe $(2014,117)$ tagged the role of the accounting academic as 'metaprofessional': requiring university educators to teach effectively and participate in the identification and discovery of new knowledge in Accounting.

This study investigated perceptions of professional identity of a group of accounting lecturers at one South African university. The main question of inquiry was whether accounting lecturers perceive themselves primarily as chartered accountants or as university lecturers. Our findings indicate that accounting lecturers at the particular university find their professional identity primarily in being professional lecturers, rather than being professional chartered accountants. This differs from a previous study by Macfarlane (1998), which concluded that lecturers who teach in professional university programmes find their identity in professional, 
rather than academic capacities. Our study also found that for the participating group, background variables did not play a significant role in professional identity formation. Although the results clearly indicate that accounting lecturers primarily find their professional identity in their lecturing capacity, they still seem to treasure their CA (SA) qualification and status. Lecturers who belong to a professional body (in this case, SAICA) are expected to remain abreast with professional knowledge and competencies, but our study also showed that the development of lecturer-related competencies is seen as of greater value by the participating group. It thus seems to be important for professional accounting lecturers to have a professional body to affiliate to, as this improves the quality of their teaching and fosters professional standards, which are central to cultivating teacher professional identity and educating future CAs (Komba et al. 2013).

To gauge lecturers' perceptions of their professional identity has important implications for academic managers and staff that support and promote professional learning for lecturers. Ignorance of primary and secondary affiliations and affinities may result in promoting unsuitable or irrelevant professional learning opportunities for accounting lecturers and may ultimately negatively influence their motivation, professional development choices and professional behaviour (Beijaard et al. 2000; Cross and Ndofirepi 2015). Such studies are thus of value, not only for professional reflection, but also for upcoming lecturers who teach in professional programmes as part of their orientation. The way in which lecturers perceive themselves, their profession and others in their profession is often reflected in their practices and affects the quality of the education they provide (Komba et al. 2013).

In turn, role conflict can also affect accounting lecturers' effectiveness (Rizzo et al. 1970), which may lead to poor professional performance. In our study, however, role conflict was not identified as being a major factor. If accounting lectures perceive themselves as university lecturers rather than CA's, the implication would be that to excel as an academic and educator would contribute towards teaching excellence. Teaching excellence includes having an advance knowledge of one's discipline and knowledge of teaching (Trigwell and Shale 2004). The behavioural intentions, commitment to teaching, motivation and efficacy are all affected by the way lecturers perceive themselves. In this study it was found that accounting lecturers perceive themselves more as lecturers than as CAs, and this can contribute to teaching excellence, as they consider the importance of the scholarship of teaching and would want to excel in their teaching activities.

Inquiry into the professional identity of accounting lecturers will remain an ongoing process as university contexts change and as new professionals enter higher education. For 
accounting lecturers, in particular, it is important to develop both as professional academics and professional chartered accountants to ensure that accounting education remains relevant and qualitatively strong. To the extent that accounting lecturers carry out both functions well, they should be able to sustain and develop the accounting profession (Wilkerson 2010) or, as reiterated by Day et al. (2006), create a positive sense of professional identity which is critical for maintaining efficiency, commitment and passion.

\section{REFERENCES}

Auyeung, P. and J. Sands. 1997. Factors influencing accounting students' career choice: A cross-cultural validation study. Accounting Education 6(1): 13-23.

Ballantyne, R., J. D. Bain and J. Packer.1999. Researching university teaching in Australia: Themes and issues in academics' reflections. Studies in Higher Education 24(2): 237-257.

Beijaard, D. 1995. Teachers' prior experiences and actual perceptions of professional identity. Teachers and Teaching: Theory and Practice 1(2): 281-294.

Beijaard, D., P. C. Meijer and N. Verloop. 2004. Reconsidering research on teachers' professional identity. Teaching and Teacher Education 20(2): 107-128.

Beijaard, D., N. Verloop and J. D. Vermunt. 2000. Teachers' perceptions of professional identity: An exploratory study from a personal knowledge perspective. Teaching and Teacher Education 16(7): 749-764.

Billot, J. 2010. The imagined and the real: Identifying the tensions for academic identity. Higher Education Research \& Development 29(6): 709-721.

Boyer, E. L. 1990. Scholarship revisited. Princeton, NJ: Carnegie Foundation for the Advancement of Teaching.

Bromme, R. 1991. Wissenstypen und professionelles Selbstverstandniss [Types of knowledge and professional self-concept]. Zeitschrift fur Paedagogik 37: 769-785.

Brownell, S. E. and K. D. Tanner. 2012. Barriers to faculty pedagogical change: Lack of training, time, incentives, and ... tensions with professional identity? CBE-Life Sciences Education 11(4): 339346.

Canrinus, E. T. 2011. Profiling teachers' sense of professional identity. Educational Studies 37(5): 593608.

Canrinus, E. T., M. Helms-Lorenz, D. Beijaard, J. Buitink and A. Hofman. 2011. Profiling teachers' sense of professional identity. Educational Studies 37(5): 593-608.

Cheung, H. Y. 2008. Measuring the professional identity of Hong Kong in-service teachers. Journal of In-Service Education 34(3): 375- 390.

Clarke, M., A. Hyde and J. Drennan. 2013. Professional identity in higher education. In The academic profession in Europe: New tasks and new challenges, ed. B. Kehm and U. Teichler, 7-21. Springer, Netherlands.

Coldron, J. and R. 1999. Active location in teachers' construction of their professional identities. Journal of Curriculum Studies 31(6): 711-726.

Costandius, E. and E. M. Bitzer. 2015. Engaging higher education curricula: A critical citizenship education perspective. Stellenbosch: SunMedia.

Cross, M. and E. Ndofirepi. 2015. On becoming and remaining a teacher: Rethinking strategies for developing teacher professional identity in South Africa. Research Papers in Education 30(1): 95-113.

Day, C., A. Kington, G. Stobart and P. Sammons. 2006. The personal and professional selves of 
teachers: Stable and unstable identities. British Educational Research Journal 32(4): 601-616.

Empson, L. 2004. Organizational identity change: Managerial regulation and member identification in an accounting firm acquisition. Accounting, Organization and Society 29(8): 759-781.

Erikson, E. H. 1968. Identity: Youth and crisis. Norton, New York.

Giroux H. A. 2014. Neoliberalism's war on higher education. Chicago: Heymarket Books.

Hamilton, N. W. 2007. Professionalism clearly defined. University of St. Thomas Legal Studies Research Paper 18(4): 7-30.

Hargreaves, A. 2000. Mixed emotions: Teachers' perceptions of their interactions with students. Teaching and Teacher Education 16(8): 811-826.

Healey, M. 2000. Developing the scholarship of teaching in higher education: A discipline-based approach. Higher Education Research and Development 19(2): 169-189.

HELTASA see Higher Education Learning and Teaching Association of Southern Africa.

Higher Education Learning and Teaching Association of Southern Africa. 2015. Professional Development, available at: http://heltasa.org.za/professional-development/ (accessed 16 July 2015).

Hong, J. Y. 2010. Pre-service and beginning teachers' professional identity and its relation to dropping out of the profession. Teaching and Teacher Education 26(8): 1530-1543.

Hooley, N. 2007. Establishing professional identity: Narrative as curriculum for pre-service teacher education. Australian Journal of Teacher Education 32(1): 49-60.

Huberman, M. 1989. The professional life cycle of teachers. The Teachers College Record 91(1): 3157.

Kerby, A. P. 1991. Narrative and the self. Bloomington: Indiana University Press.

King, V. 2013. Self-portrait with mortar board: A study of academic identity using the map, the novel and the grid. Higher Education Research \& Development 32(1): 96-108.

King, V., A. Garcia-Perez, R. Graham, C. Jones, A. Tickle and L. Wilson. 2014. Collaborative reflections on using island maps to express new lecturers' academic identity. Reflective Practice 15(2): 252-267.

Komba, W. L., W. A. Anangisye and J. K. Katabaro. 2013. The development of teacher professional identity at the University of Dar es Salaam: Perceptions and influencing factors. Journal of International Cooperation in Education 15(3): 187-204.

Lubbe, I. 2014. Education professionals: Describing the knowledge agency of Accounting academics. Meditari Accountancy Research 22(1): 107-127.

Macfarlane, B. 1998. Business lecturers in higher education: Outsider reputations, insider values. Paper presented at Higher Education Close Up conference, 6-8 July 1998, University of Central Lancashire, Preston. http://www.leeds.ac.uk/educol/documents/000000678.htm (accessed 30 June 2015).

Marcelo, C. 2009. Professional development of teachers: past and future. Sisifo Educational Sciences Journal 8: 5-20.

Moore, M. and J. E. Hofman. 1988. Professional identity in institutions of higher learning in Israel. Higher education 17(1): 69-79.

Nieuwoudt, M. J., J. S. Wilcocks and O. V. Kilpert. 2006. Time perceptions of South African accounting academics about research. Meditari Accountancy Research 14(2): 17-32.

Retief Venter, E. and C. de Villiers. 2013. The accounting profession's influence on academe: South African evidence. Accounting, Auditing \& Accountability Journal 26(8): 1246-1278.

Rizzo, J. R., R. J. House and S. I. Lirtzman. 1970. Role conflict and ambiguity in complex organizations. Administrative Science Quarterly: 150-163.

SAICA see South African Institute for Chartered Accountants. 
South African Institute for Chartered Accountants. 2013. CPD philosophy and strategy. https://www. saica.co.za/Members/ContinuingProfessionalDevelopment/CPDPhilosophyandStrategy/tabid/75 1/language/en-ZA/Default.aspx (accessed 2 July 2015).

South African Institute for Chartered Accountants. 2015. Becoming a CA. https://www.saica.co.za/ Training/BecomingaCA/tabid/157/language/en-ZA/Default.aspx (accessed 2 July 2015).

Samkin, G. and A. Schneider. (2014a). The accounting academic. Meditari Accountancy Research 22(1), 2-19.

Samkin, G. and A. Schneider. 2014b. Using university websites to profile accounting academics and their research output: A three country study. Meditari Accountancy Research 22(1): 77-106.

Shaftel, J. and T. L. Shaftel. 2005. The influence of effective teaching in accounting on student attitudes, behavior, and performance. Issues in Accounting Education 20(3): 231-246.

Sherman, T. M., L. P. Armistead, F. Fowler, M. A. Barksdale and G. Reif. 1987. The quest for excellence in university teaching. The Journal of Higher Education: 66-84.

Simon, H. A. 1976. Administrative Behavior. Third edition. New York: Free Press.

Skelton, A. 2004. Understanding 'teaching excellence' in higher education: a critical evaluation of the National Teaching Fellowships Scheme. Studies in Higher Education, 29(4): 451-468.

Steenkamp, L. P. and P. L. Wessels. 2009. An investigation into students' perceptions of accountants. Meditari Accountancy Research 17(1): 117-132.

Stone, S., B. Ellers, D. Holmes, R. Orgren, D. Qualters and J. Thompson. 2002. Identifying oneself as a teacher: The perceptions of preceptors. Medical Education 36(2): 180-185.

Sugrue, C. 1997. Student teachers' lay theories and teaching identities: Their implications for professional development. European Journal of Teacher Education 20(3): 213-225.

Sumara, D. J. and R. Luce-Kapler. 1996. (Un) becoming a teacher: Negotiating identities while learning to teach. Canadian Journal of Education/Revue canadienne de l'education: 65-83.

SU Strategy for Teaching and Learning. 2015. Email to E.de Jager, 1 December 2015, Available email: edejager@sun.ac.za.

Taylor, P. G. 1999. Making sense of academic life: Academics, universities and change. Florence: Taylor and Francis Group.

Trede, F., R. Macklin and D. Bridges. 2012. Professional identity development: A review of the higher education literature. Studies in Higher Education 37(3): 365-384.

Trigwell, K. and S. Shale. 2004. Student learning and the scholarship of university teaching. Studies in Higher Education, 29(4): 523-536.

University of Manchester. 2015. An academic career. http://www.academiccareer.manchester.ac.uk/ foryou/postdoc/stay/ (accessed 8 June 2015).

Waghid, Y. 2006. University education and deliberation: In defence of practical reasoning. Higher Education 51(3): 315-328.

Waghid, Y. 2009. Education for responsible citizenship. Perspectives in Education 27(1): 85-90.

Weiss, I. and S. Fisherman. 2006. Running head teachers' training'. http://www.google.co.za/ url?sa=t\&rct=j\&q=\&esrc=s\&source=web\&cd=1\&ved=0CCEQFjAA\&url=http\%3A\%2F\%2Fw ww.orot.ac.il\%2FM-ed\%2Feducational-consultancy\%2Fmaterials\%2Fproporsal\%2520weiss\% 2520with\%2520fisherman\%2520august\%25202006.doc\&ei=E3FtVfvuDYXwUIzSgdAB\&usg= AFQjCNHqB7LE3glwGFK8WYuDeAiWeZUuuw\&sig2=zcSK2qQAxaUabMpoXCmMWw (accessed 15 July 2015).

Wells, G. and Edwards, G (2013). Pedagogy in higher education: A cultural historical approach. New York: Cambridge University Press.

Wilkerson, J. E. 2010. Accounting educators as the accounting profession's trustees: Lessons from a study of peer professions. Issues in Accounting Education 25(1): 1-13. 